\title{
Harmful algae and export production collapse in the equatorial Atlantic during the zenith of Middle Eocene Climatic Optimum warmth
}

\author{
Margot J. Cramwinckel ${ }^{1}$, Robin van der Ploeg ${ }^{1}$, Peter K. Bijl1', Francien Peterse ${ }^{1}$, Steven M. Bohaty², Ursula Röhl \\ Stefan Schouten ${ }^{1,4}$, Jack J. Middelburg', and Appy Sluijs ${ }^{1}$ \\ 'Department of Earth Sciences, Faculty of Geoscience, Utrecht University, 3584 CB Utrecht, Netherlands \\ 2Ocean and Earth Science, National Oceanography Centre Southampton, University of Southampton, SO14 3ZH Southampton, UK \\ ${ }^{3}$ MARUM - Center for Marine Environmental Sciences, University of Bremen, 28359 Bremen, Germany \\ ${ }^{4}$ Department of Marine Microbiology and Biogeochemistry, NIOZ Royal Netherlands Institute for Sea Research, and Utrecht \\ University, 1790 AB Den Burg, Texel, Netherlands
}

\begin{abstract}
New palynological, sedimentological, and geochemical records spanning the Middle Eocene Climatic Optimum (MECO; ca. $40 \mathrm{Ma}$ ) in the equatorial Atlantic Ocean indicate that peak warming was associated with upper-ocean stratification, decreased export production, and possibly harmful algal blooms, followed by slight oxygen minimum zone expansion. Combining these findings with published MECO records suggests that export production collapse and benthos starvation during the zenith of MECO warmth were widespread in the Atlantic. Furthermore, comparison to records across the Paleocene-Eocene thermal maximum (ca. $56 \mathrm{Ma}$ ) at the same site suggests a similar system response to warming, but with different impact on benthic communities.
\end{abstract}

\section{INTRODUCTION}

Rapidly rising atmospheric $\mathrm{CO}_{2}$ concentrations are currently driving upper-ocean warming and acidification (IPCC, 2013). Warming and associated intensification of the hydrological cycle contribute to stronger upper-ocean stratification and expansion of oxygen minimum zones (OMZs), particularly in regions already prone to these conditions, such as low-latitude regions (Stramma et al., 2008). Moreover, warming in conjunction with nutrient-rich runoff and stratification is increasing the global occurrence of harmful algal blooms (HABs), including toxic dinoflagellate blooms (Fu et al., 2012). Both OMZ expansion and HAB development have detrimental economical and ecological effects on coastal areas (Anderson et al., 2012), and prediction of their occurrence in a progressively warmer climate is an urgent challenge.

Past events of climate change allow assessment of marine environmental and ecological responses to warming. Records of Paleogene transient global warming events such as the Paleocene-Eocene thermal maximum (PETM; ca. $56 \mathrm{Ma}$ ) indicate stratification, OMZ expansion, increased phytoplankton productivity (Carmichael et al., 2017), and perhaps HABs (Sluijs et al., 2018). Comparatively little is known about the environmental effects of more gradual warming phases, such as the Middle Eocene Climatic Optimum (MECO; ca. $40 \mathrm{Ma}$ ). While the MECO reached less extreme maximum temperatures than the PETM, the magnitude of deep- and surface-ocean warming of $3-6{ }^{\circ} \mathrm{C}$ was comparable (Bohaty et al., 2009; Dunkley Jones et al., 2013). Warming, biotic turnover, and OMZ expansion during the PETM have recently been documented at Ocean Drilling Program (ODP) Site 959 in the eastern equatorial Atlantic Ocean (Frieling et al., 2018). We generated similar palynological, sedimentological, and geochemical records at the same site to assess the tropical response to MECO warming.

\section{MATERIAL}

ODP Site $959\left(3.6276^{\circ} \mathrm{N}, 2.7352^{\circ} \mathrm{W}\right)$ is located in the Deep Ivorian Basin offshore West Africa, near the crest of the subsided Cote d'Ivoire-Ghana Marginal Ridge (Mascle et al., 1996). In the modern ocean, this region is characterized by seasonal upwelling and phytoplankton blooms (Signorini et al., 1999) and an OMZ at 400-500 m water depth (Karstensen et al., 2008). During the MECO, the site was also positioned at bathyal depths and equatorial latitudes (Fig. 1). Middle-upper Eocene sediments at Site 959 consist of relatively organic-rich, carbonate-lean, porcellanites (diagenetically altered biogenic silica) and siliciclastics, suggesting a similar high-productivity setting (Mascle et al., 1996; Wagner, 2002). The MECO interval at Site 959 was previously identified based on biostratigraphy, chemostratigraphy, and paleothermometry (Cramwinckel et al., 2018; van der Ploeg et al., 2018; see the GSA Data Repository ${ }^{1}$ ).

\section{METHODS}

We used palynological materials from the study of Cramwinckel et al. (2018) for quantitative determination of dinocyst abundance. Bulk sediment elemental compositions were determined using inductively coupled plasmaoptical emission spectrometry (ICP-OES; Perkin Elmer Optima 3000) in total acid-digested solutions. Stable carbon $\left(\delta^{13} \mathrm{C}\right)$ and oxygen $\left(\delta^{18} \mathrm{O}\right)$ isotope ratios of bulk carbonate were measured using a Thermo Scientific Kiel IV carbonate

${ }^{1}$ GSA Data Repository item 2019090, methods, Figure DR1 (additional geochemical and palynological records of oceanographic and environmental change during the MECO at ODP Site 959), Figure DR2 (images of the dinocyst Polysphaeridium zoharyi), Table DR1 (bioturbation types and maximum burrow diameter of ODP Hole 959D, core 13R-23R), and Table DR2 (summary of inferred [export] productivity change during the MECO), is available online at http://www.geosociety.org /datarepository/2019/, or on request from editing@geosociety.org.

CITATION: Cramwinckel, M.J., et al., 2019, Harmful algae and export production collapse in the equatorial Atlantic during the zenith of Middle Eocene climatic optimum warmth: Geology, v. 47, p. 247-250, https://doi.org/10.1130/G45614.1 


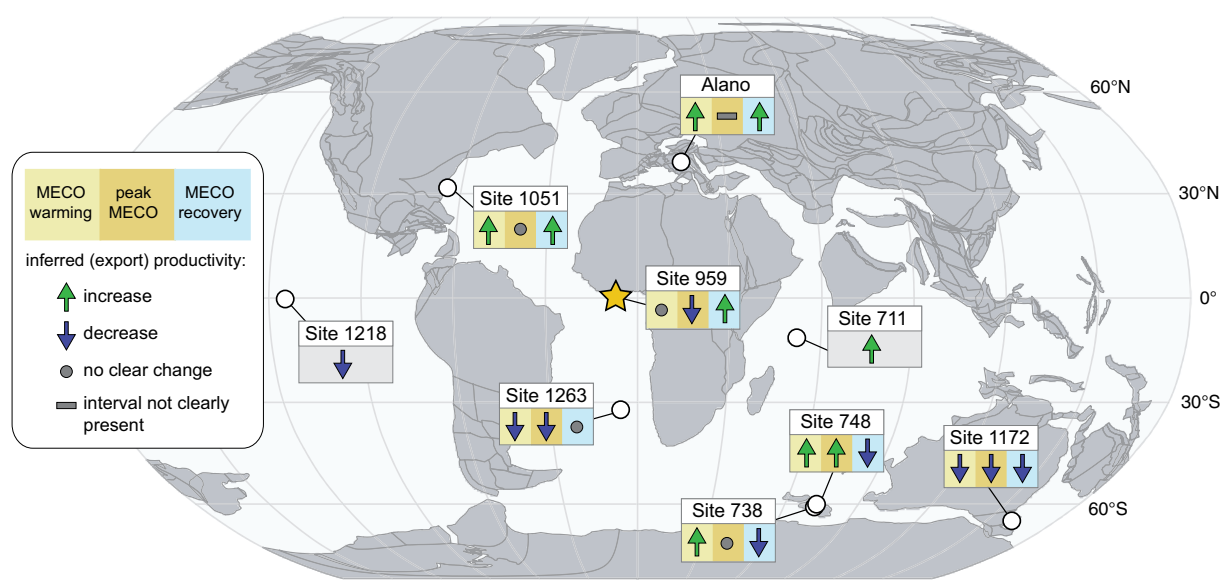

Figure 1. Paleogeographic map (40 Ma) of published (white dots) and present (yellow star) middle Eocene climatic optimum (MECO) Ocean Drilling Program (ODP) study sites and Alano section. Inferred relative change in (export) productivity was reconstructed at selected sites showing increases (up arrows) or decreases (down arrows) during MECO warming (column 1, yellow), MECO peak (column 2, orange), and MECO recovery (column 3, light blue). Dash indicates no clearly defined peak interval, whereas dot indicates no clear (export) productivity change. For ODP Sites 1218 and 711, constraints to subdivide the MECO into intervals are lacking. Figure is based on literature compilation as in Table DR2 (see footnote 1). Map was produced using GPlates.

device coupled to a Thermo Scientific MAT 253 isotope ratio mass spectrometer (IRMS). Total organic carbon (TOC) and nitrogen contents were measured on decalcified bulk sediment using a Fisons elemental analyzer, and stable carbon isotope ratios of TOC $\left(\delta^{13} \mathrm{C}_{\text {org }}\right)$ were subsequently determined using a Finnigan DELTAplus IRMS. Polar fractions separated from the total lipid extracts of Cramwinckel et al. (2018) were desulfurized for five samples across the MECO interval, which were then analyzed by gas chromatography-mass spectrometry to assess the presence of isorenieratene and derivatives. For characterization of bioturbation, highresolution images were made using a GEOTEK Geoscan-III line-scan camera (see the GSA Repository for detailed methods).

\section{RESULTS AND DISCUSSION}

\section{Surface-Ocean Conditions}

\section{Background Middle Eocene Setting}

A productive oceanographic setting at Site 959 during the middle Eocene is indicated by several lines of evidence, including relatively high abundances of heterotrophic protoperidinioid dinocysts and a biosiliceous lithology with relatively high TOC (Fig. 2). Fairly low abundances of detrital components (Al, Ti, $\mathrm{Fe}, \mathrm{Zr}$, and $\mathrm{K}$ ), negligible amounts of terrestrial palynomorphs and lipid biomarkers, and $\delta^{13} \mathrm{C}_{\text {org }}$ values ( $-25 \%$ and $-27 \%$ ) consistent with Eocene marine organic matter (Hayes et al., 1999) indicate that terrigenous input was limited (Supplementary Data). Dinocyst assemblages are dominated by the open-marine taxa Spiniferites spp. and Operculodinium spp. Based on these observations, productivity was dominantly fueled by upwelling rather than fluvial to recorded blooms of this species in the Arabian Sea during phases of hyperstratification in warm Pleistocene interstadials (Reichart et al., 2004). We suggest similarly strong thermally induced stratification facilitated the complete life cycle of $P$. zoharyi during the zenith of MECO warmth in the equatorial Atlantic. Although we cannot assess if high $P$. zoharyi cyst abundance reflects true biological blooms, as abundances in cells per liter of paleoseawater cannot be determined, these harmful algae were certainly abundant in particulate matter exported to the seafloor.

\section{Subsurface and Seafloor Conditions}

\section{Background Middle Eocene Setting}

Our reconstructions of seafloor conditions suggest that inferred high sea-surface productivity throughout the middle Eocene study interval at Site 959 was linked to high organic matter export fluxes. Sediments are relatively rich in TOC (averaging $\sim 1.6 \%$ ), palynomorph preservation is good, and, overall, trace-element concentrations mirror the geochemical composition of sediments underlying upwelling sediments in the modern ocean (Brumsack, 2006) (Fig. 2). Especially in the younger part of the record, $\mathrm{C}_{\text {org }} / \mathrm{P}_{\text {tot }}$ values rise markedly above those associated with the Redfield ratio of algal matter $\left(\mathrm{C}_{\text {org }} / \mathrm{P}_{\text {tot }} \approx 106\right)$, indicating some regeneration of $\mathrm{P}$ resulting from low-oxygen conditions at the seafloor. However, the trace fossil assemblage (Planolites, Chondrites, Zoophycos, Thalassinoides, and Teichichnus; Fig. 3; Table DR1) and consistent presence of organic benthic foraminiferal linings and $\mathrm{Mn}$ (Fig. 2; Fig. DR1) throughout the Site 959 study section indicate at least occasional seafloor oxygenation. Combined, these lines of evidence indicate that an extensive midwater OMZ was likely present, although the seafloor was not hypoxic.

In the post-MECO interval (560-500 mbsf), TOC contents increase progressively, and redoxsensitive trace elements, including $\mathrm{Zn}, \mathrm{Ni}, \mathrm{Cr}$, $\mathrm{Cu}, \mathrm{V}$, and particularly Mo, record slight enrichments (i.e., typically $<100$ ppm; Fig. 2). We interpret this as vertical expansion or intensification of the OMZ toward the seafloor. This is consistent with inferred increasing productivity due to long-term strengthening of upwelling throughout the late post-MECO Eocene at Site 959 (Wagner, 2002; Cramwinckel et al., 2018).

\section{Export Production and Benthic Food Limitation during the MECO}

Within the MECO interval at Site 959, redox tracers and TOC together indicate more reducing bottom water conditions compared to the pre-MECO interval. Isorenieratene or its derivatives were not detected, however, suggesting that photic zone euxinia did not develop during the MECO. Synchronous with peak MECO warming and the P. zoharyi acme, ichnofossils derived from burrowing organisms decrease in average diameter, and benthic foraminiferal 
Figure 2. Geochemical and palynological records of oceanographic and environmental change during middle Eocene climatic optimum (MECO) at Ocean Drilling Program (ODP) Site 959. Core recovery in black; mbsf-meters below seafloor. A: Seasurface temperature (SST) reconstruction based on index of tetraethers consisting of 86 carbon atoms $\left(\right.$ TEX $_{86}$ ) and the $\operatorname{TEX}_{86}{ }^{\mathrm{H}}$ calibration; Cramwinckel et al., 2018). Based on this, yellow shading represents MECO warming, orange shading is peak MECO, and light blue shading is MECO recovery. B: Relative (\% of total dinocysts, green shading) and absolute (dinocysts/g, black line) abundances of Polysphaeridium spp.

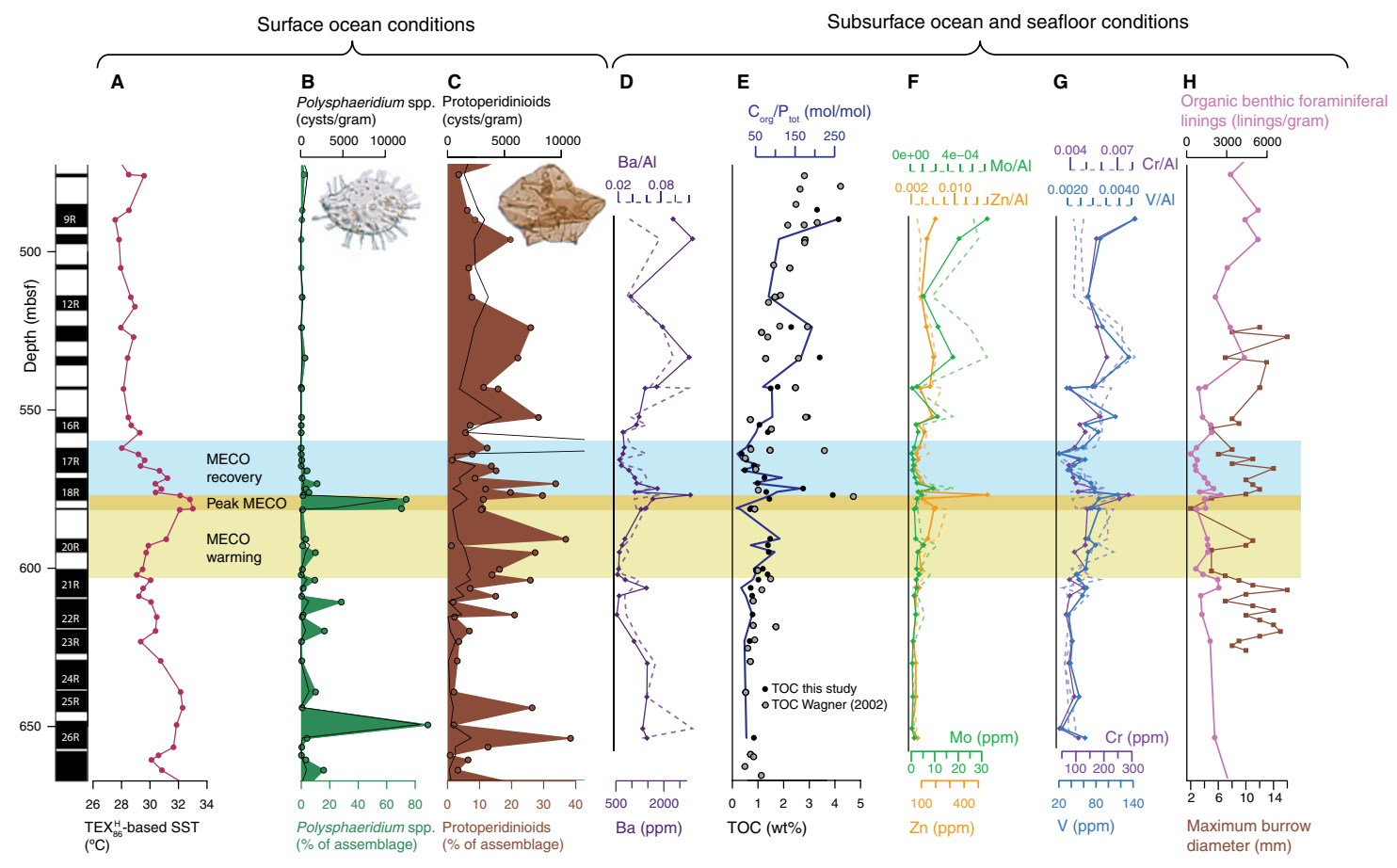

C: Relative (\% of total dinocysts, green shading) and absolute (dinocysts/g, black line) abundances of heterotrophs (protoperidinioids). Note: one absolute $(24,000)$ dinocysts/g data point at 562.04 mbsf is off scale. D: Barium (Ba) contents in ppm (solid lines) and normalized to aluminum (Al; dotted lines). E: Total organic carbon (TOC; wt\%; black dots-this study; gray dots-from Wagner, 2002) and molar $\mathbf{C}_{\text {org }} / \mathbf{P}_{\text {tot }}$ ratio (blue line). F: Molybdenum (Mo; green) and zinc (Zn; orange) contents in ppm (solid lines) and normalized to Al (dotted lines). G: Chromium ( $\mathrm{Cr}$; purple) and vanadium (V; blue) contents in ppm (solid lines) and normalized to Al (dotted lines). $\mathrm{H}$ : Maximum burrow diameter $(\mathrm{mm})$ per section of core, plotted against midpoint of core (brown) and benthic foraminiferal lining content (linings/gram; pink).

linings decrease in abundance (Fig. 2). This benthic community change was likely unrelated to seafloor deoxygenation, as peak OMZ expansion (based on $\mathrm{Cr}, \mathrm{Cu}, \mathrm{V}$, and $\mathrm{Zn}$ increase) and potential increases in productivity (based on $\mathrm{Ba}$ and TOC increase) at 577 mbsf postdate peak MECO warmth ( $580 \mathrm{mbsf})$. Organic carbon delivery to the sediments is a major factor governing the body size of benthic organisms (Rex et al., 2006). We therefore interpret the decrease in size of bioturbating benthos as resulting from decreased organic carbon delivery to the seafloor during peak MECO warmth. Enhanced warmth likely added to seafloor food shortages by decreasing the efficiency of export productivity and by increasing organic carbon remineralization in warm subsurface waters (Laws et al., 2000). Combined, we infer that intensified thermal stratification during peak MECO suppressed upwelling and thus sea-surface (export) productivity, resulting in seafloor food shortage. These changes were immediately followed by increasing productivity and subsurface deoxygenation during the MECO recovery phase.

Combined with published results, these data reveal spatially variable environmental and ecological change across the MECO (Fig. 1; see also references in Table DR2). Peak MECO warmth was also linked to decreased export productivity and benthos starvation at ODP Site 1263 in the South Atlantic, based on coupled plankticbenthic records (Boscolo-Galazzo et al., 2014,
2015), suggesting this response was widespread in the Atlantic, possibly through stratification. Dinocyst assemblages from the southwest Pacific also indicate more oligotrophic conditions during the MECO (Bijl et al., 2010). In contrast, records of planktonic siliceous and carbonate microfossils from the Southern Ocean and Tethys indicate increased surface-ocean productivity that in turn stimulated benthic communities (e.g., Witkowski et al., 2012; Luciani et al., 2010; Table DR2). These regional differences testify to a pronounced change in global ocean nutrient distribution across the MECO.
A

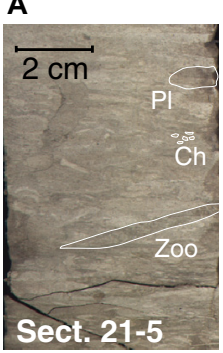

B

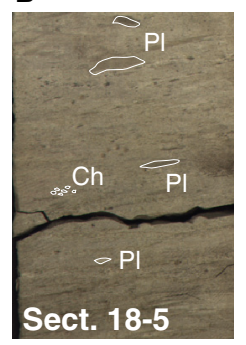

C

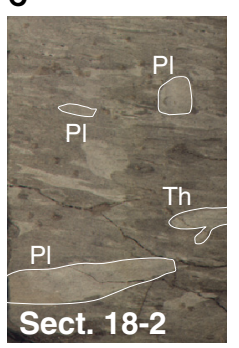

Comparison of System Response to MECO and PETM at ODP Site 959

The Eocene record at Site 959 provides the unique opportunity to compare the system response to warming between the PETM (Frieling et al., 2018) and the MECO. Warming of $\sim 4{ }^{\circ} \mathrm{C}$ led to seawater deoxygenation during both events, although the middle Eocene highproductivity background setting was possibly more susceptible to OMZ expansion compared to the late Paleocene (Wagner, 2002). Intriguingly, while the benthos was adversely affected during the MECO at Site 959, the PETM is
Figure 3. Photos showing characteristic types of bioturbation encountered in middle Eocene cores from Ocean Drilling Program (ODP) Hole 959D. A: Pre-middle Eocene climatic optimum (MECO) section 959D-21R-5A, interval 39-48 cm, single Zoophycos (Zoo), large and small Planolites (PI), Chondrites (Ch). B: Peak MECO 959D-18R-5A, 44-53 cm, only some small Planolites and Chondrites. C: MECO recovery 959D-18R-2A, 54-63 cm, large and small Planolites, Chondrites, and Thalassinoides (Th) in light sediment. D: MECO recovery 959D-17R-3A, 80-89 cm, large and small Planolites, Chondrites, and Thalassinoides in dark sediment. E: MECO recovery 959D-17R-3A, 37-45 cm, multiple Zoophycos, large and small Planolites, Chondrites, and Teichichnus (Tc). Some example burrows have been highlighted in white. 
instead marked by increased amounts of benthic foraminiferal linings and sustained bioturbation. Another difference is the sharp regional demise of eukaryotic primary producers during peak PETM warmth (Frieling et al., 2017, 2018), likely related to higher absolute temperatures than those reached during the MECO.

\section{CONCLUSIONS}

We reconstruct short-lived stratified conditions and high abundance of harmful algae during peak MECO warmth at eastern equatorial Atlantic ODP Site 959, that led to a drop in export production and food limitation of benthic communities. Compilation of these data with other available MECO records (BoscoloGalazzo et al., 2014, 2015) suggests that export production collapse and benthos starvation during the zenith of MECO warmth might have been widespread in the Atlantic Ocean. At Site 959, these oceanographic and biological changes were immediately followed by subsurface deoxygenation as stratification decreased. Qualitatively, these changes are analogous to present-day trends (Breitburg et al., 2018; Fu et al., 2012), underlining the observation that development of stratification and deoxygenation is an inherent Earth system response to warming. The occurrence of possible harmful dinoflagellate blooms during the MECO is also qualitatively similar to modern trends and suggests that future warming and stratification are increasingly preconditioning oceans for harmful algal blooms.

\section{ACKNOWLEDGMENTS}

We thank Tim Bralower and two anonymous reviewers for constructive comments that improved the manuscript. This research used samples and data provided by the International Ocean Discovery Program (IODP) and its predecessors. We thank the Netherlands Earth System Science Centre (NESSC), financially supported by the Dutch Ministry of Education, Culture and Science. Sluijs thanks the European Research Council for Consolidator grant 771497. We thank Ellen Thomas for providing benthic foraminiferal lining identifications; Thomas Wagner for providing total organic carbon data; Niels van Helmond, Joost Frieling, and Matthew Huber for discussions; and Giovanni Dammers, Arnold van Dijk, Coen Mulder, Natasja Welters (Utrecht Geolab), Vera Lukies (MARUM), and Anchelique Mets (NIOZ) for analytical support.

\section{REFERENCES CITED}

Anderson, D.M., Cembella, A.D., and Hallegraeff, G.M., 2012, Progress in understanding harmful algal blooms: Paradigm shifts and new technologies for research, monitoring, and management: Annual Review of Marine Science, v. 4, p. 143-176, https:// doi.org/10.1146/annurev-marine-120308-081121.

Bijl, P.K., Houben, A.J.P., Schouten, S., Bohaty, S.M., Sluijs, A., Reichart, G.-J., Damsté, J.S.S., and Brinkhuis, H., 2010, Transient middle Eocene atmospheric $\mathrm{CO}_{2}$ and temperature variations: Science, v. 330, p. 819-821, https://doi.org/10.1126 /science.1193654.

Bohaty, S.M., Zachos, J.C., Florindo, F., and Delaney, M.L., 2009, Coupled greenhouse warming and deep-sea acidification in the middle Eocene: Paleoceanography, v. 24, PA2207, https://doi.org/10 .1029/2008PA001676.
Boscolo-Galazzo, F., Thomas, E., Pagani, M., Warren, C., Luciani, V., and Giusberti, L., 2014, The middle Eocene climatic optimum (MECO): A multiproxy record of paleoceanographic changes in the southeast Atlantic (ODP Site 1263, Walvis Ridge): Paleoceanography, v. 29, PA002670, https://doi.org/10.1002/2014PA002670.

Boscolo-Galazzo, F., Thomas, E., and Giusberti, L., 2015, Benthic foraminiferal response to the Middle Eocene climatic optimum (MECO) in the south-eastern Atlantic (ODP Site 1263): Palaeogeography, Palaeoclimatology, Palaeoecology, v. 417, p. 432-444, https://doi.org/10.1016/j .palaeo.2014.10.004

Breitburg, D., et al., 2018, Declining oxygen in the global ocean and coastal waters: Science, v. 359, eaam7240, https://doi.org/10.1126/science .aam7240.

Brumsack, H.-J., 2006, The trace metal content of recent organic carbon-rich sediments: Implications for Cretaceous black shale formation: Palaeogeography, Palaeoclimatology, Palaeoecology, v. 232, p. 344-361, https://doi.org/10 .1016/j.palaeo.2005.05.011.

Carmichael, M.J., et al., 2017, Hydrological and associated biogeochemical consequences of rapid global warming during the Paleocene-Eocene thermal maximum: Global and Planetary Change, v. 157, p. 114-138, https://doi.org/10.1016/j .gloplacha.2017.07.014.

Cramwinckel, M.J., et al., 2018, Synchronous tropical and polar temperature evolution in the Eocene: Nature, v. 559, p. 382-386, https://doi.org/10 .1038/s41586-018-0272-2.

Dunkley Jones, T., Lunt, D.J., Schmidt, D.N., Ridgwell, A., Sluijs, A., Valdes, P.J., and Maslin, M., 2013, Climate model and proxy data constraints on ocean warming across the Paleocene-Eocene thermal maximum: Earth-Science Reviews, v. 125 , p. 123-145, https://doi.org/10.1016/j .earscirev.2013.07.004.

Frieling, J., Gebhardt, H., Huber, M., Adekeye, O.A., Akande, S.O., Reichart, G.-J., Middelburg, J.J., Schouten, S., and Sluijs, A., 2017, Extreme warmth and heat-stressed plankton in the tropics during the Paleocene-Eocene thermal maximum: Science Advances, v. 3, e1600891, https://doi.org /10.1126/sciadv.1600891.

Frieling, J., Reichart, G.-J., Middelburg, J.J., Röhl, U., Westerhold, T., Bohaty, S.M., and Sluijs, A., 2018, Tropical Atlantic climate and ecosystem regime shifts during the Paleocene-Eocene thermal maximum: Climate of the Past, v. 14, p. 39-55, https://doi.org/10.5194/cp-14-39 -2018 .

Fu, F.X., Tatters, A.O., and Hutchins, D.A., 2012 , Global change and the future of harmful algal blooms in the ocean: Marine Ecology Progress Series, v. 470, p. 207-233, https://doi.org/10 .3354/meps 10047 .

Hayes, J.M., Strauss, H., and Kaufman, A.J., 1999, The abundance of ${ }^{13} \mathrm{C}$ in marine organic matter and isotopic fractionation in the global biogeochemical cycle of carbon during the past $800 \mathrm{Ma}$ : Chemical Geology, v. 161, p. 103-125, https://doi .org/10.1016/S0009-2541(99)00083-2.

Intergovernmental Panel on Climate Change (IPCC), 2013, Climate Change 2013: The Physical Science Basis. Contribution of Working Group I to the Fifth Assessment Report of the Intergovernmental Panel on Climate Change (Stocker, T.F., et al., eds.): Cambridge, UK, Cambridge University Press, 1535 p., https://doi.org/10.1017 /CBO9781107415324.

Karstensen, J., Stramma, L., and Visbeck, M., 2008, Oxygen minimum zones in the eastern tropical Atlantic and Pacific oceans: Progress in
Oceanography, v. 77, p. 331-350, https://doi.org /10.1016/j.pocean.2007.05.009.

Laws, E.A., Falkowski, P.G., Smith, W.O., Ducklow, H., and McCarthy, J.J., 2000, Temperature effects on export production in the open ocean: Global Biogeochemical Cycles, v. 14, p. 1231-1246, https://doi.org/10.1029/1999GB001229.

Luciani, V., Giusberti, L., Agnini, C., Fornaciari, E., Rio, D., Spofforth, D.J.A., and Pälike, H., 2010, Ecological and evolutionary response of Tethyan planktonic foraminifera to the middle Eocene climatic optimum (MECO) from the Alano section (NE Italy): Palaeogeography, Palaeoclimatology, Palaeoecology, v. 292, p. 82-95, https://doi.org /10.1016/j.palaeo.2010.03.029.

Marret, F., 1994, Distribution of dinoflagellate cysts in recent marine sediments from the east equatorial Atlantic (Gulf of Guinea): Review of Palaeobotany and Palynology, v. 84, p. 1-22, https://doi .org/10.1016/0034-6667(94)90038-8.

Mascle, J., Lohmann, G.P., Clift, P.D., and Shipboard Scientific Party, 1996, Proceedings of the Ocean Drilling Program Initial Reports, Volume 159: College Station, Texas, Ocean Drilling Program, https://doi.org/10.2973/odp.proc.ir.159.1996.

Reichart, G.-J., Brinkhuis, H., Huiskamp, F., and Zachariasse, W.J., 2004, Hyperstratification following glacial overturning events in the northern Arabian Sea: Paleoceanography, v. 19, PA2013, https://doi.org/10.1029/2003PA000900.

Rex, M.A., Etter, R.J., Morris, J.S., Crouse, J., McClain, C.R., Johnson, N.A., Stuart, C.T., Deming, J.W., Thies, R., and Avery, R., 2006, Global bathymetric patterns of standing stock and body size in the deep-sea benthos: Marine Ecology Progress Series, v. 317, p. 1-8, https://doi.org/10 .3354/meps317001.

Signorini, S.R., Murtugudde, R.G., McClain, C.R., Christian, J.R., Picaut, J., and Busalacchi, A.J., 1999, Biological and physical signatures in the tropical and subtropical Atlantic: Journal of Geophysical Research-Oceans, v. 104, p. 18,36718,382, https://doi.org/10.1029/1999JC900134.

Sluijs, A., van Roij, L., Frieling, J., Laks, J., and Reichart, G.-J., 2018, Single-species dinoflagellate cyst carbon isotope ecology across the Paleocene-Eocene thermal maximum: Geology, v. 46, p. 79-82, https://doi.org/10.1130/G39598.1.

Stramma, L., Johnson, G.C., Sprintall, J., and Mohrholz, V., 2008, Expanding oxygen-minimum zones in the tropical oceans: Science, v. 320, p. 655-658, https://doi.org/10.1126/science.1153847.

Usup, G., Ahmad, A., Matsuoka, K., Lim, P.T., and Leaw, C.P., 2012, Biology, ecology and bloom dynamics of the toxic marine dinoflagellate Pyrodinium bahamense: Harmful Algae, v. 14, p. 301312, https://doi.org/10.1016/j.hal.2011.10.026.

van der Ploeg, R., Selby, D., Cramwinckel, M.J., Li, Y., Bohaty, S.M., Middelburg, J.J., and Sluijs, A., 2018, Middle Eocene greenhouse warming facilitated by diminished weathering feedback: Nature Communications, v. 9, p. 2877, https:// doi.org/10.1038/s41467-018-05104-9.

Wagner, T., 2002, Late Cretaceous to early Quaternary organic sedimentation in the eastern equatorial Atlantic: Palaeogeography, Palaeoclimatology, Palaeoecology, v. 179, p. 113-147, https://doi.org /10.1016/S0031-0182(01)00415-1.

Witkowski, J., Bohaty, S.M., McCartney, K., and Harwood, D.M., 2012, Enhanced siliceous plankton productivity in response to middle Eocene warming at Southern Ocean ODP Sites 748 and 749: Palaeogeography, Palaeoclimatology, Palaeoecology, v. 326-328, p. 78-94, https://doi.org /10.1016/j.palaeo.2012.02.006.

Printed in USA 